\title{
Fructosamine Measurement
}

National Cancer Institute

\section{Source}

National Cancer Institute. Fructosamine Measurement. NCI Thesaurus. Code C74678.

The determination of the amount of fructosamine present in a sample. 